IZA DP No. 6537

Paid Work after Retirement:

Recent Trends in Denmark

Mona Larsen

Peder J. Pedersen

May 2012 


\title{
Paid Work after Retirement: Recent Trends in Denmark
}

\author{
Mona Larsen \\ Danish National Center for Social Research \\ Peder J. Pedersen \\ Aarhus University \\ and IZA
}

Discussion Paper No. 6537

May 2012

IZA

P.O. Box 7240

53072 Bonn

Germany

Phone: +49-228-3894-0

Fax: +49-228-3894-180

E-mail: iza@iza.org

\begin{abstract}
Any opinions expressed here are those of the author(s) and not those of IZA. Research published in this series may include views on policy, but the institute itself takes no institutional policy positions.

The Institute for the Study of Labor (IZA) in Bonn is a local and virtual international research center and a place of communication between science, politics and business. IZA is an independent nonprofit organization supported by Deutsche Post Foundation. The center is associated with the University of Bonn and offers a stimulating research environment through its international network, workshops and conferences, data service, project support, research visits and doctoral program. IZA engages in (i) original and internationally competitive research in all fields of labor economics, (ii) development of policy concepts, and (iii) dissemination of research results and concepts to the interested public.
\end{abstract}

IZA Discussion Papers often represent preliminary work and are circulated to encourage discussion. Citation of such a paper should account for its provisional character. A revised version may be available directly from the author. 


\section{ABSTRACT}

\section{Paid Work after Retirement: Recent Trends in Denmark}

The labor market in Denmark seems to follow the trend in a number of other countries of increasing labor force participation in the 60+ group. We analyze trends for the early retirement age interval 60-64 and for the age group 65-74 where people are eligible to a national social security program from age 65. Until now, the increase in labor force participation has been most pronounced among 60-64-year-olds and among women. We find significant impact on work after retirement from education, gender, home ownership, aggregate unemployment at the time of retirement, age and education. Being married has a positive impact for men and a negative impact for women. We relate labor force participation after retirement to the cyclical situation and to the several policy reforms introduced since 1980.

JEL Classification: H55, J14, J26

Keywords: labor force participation, retirement

Corresponding author:

Peder J. Pedersen

Department of Economics and Business

Bartholins Alle 10

Aarhus University

8000 Aarhus C

Denmark

E-mail: ppedersen@econ.au.dk

\footnotetext{
${ }^{\star}$ We are grateful for competent research assistance from Katrine Pedersen and Palle Sørensen. An earlier version of the paper was presented at the annual conference at The Danish National Centre for Social Research in 2011. We received very useful comments from the discussant Stephen Jenkins and from other participants at the conference.
} 


\section{Introduction}

In Denmark as in most other rich OECD countries the demographic prospects until the middle of the century is characterized by an increasing share of the population being 65 years and older. This perspective is the net outcome of a fairly low level of fertility in combination with an increase in longevity. On the labor market there has - until recently - been a trend towards early retirement.

These trends represent an obvious challenge to the welfare state and are the background for broad policy discussions of initiatives or instruments to increase labor force participation. One specific area is the discussion of reforms of retirement programs resulting in an increase in the average age at which older workers enter an early or a normal retirement program. Countries that do not succeed in increasing labor force participation rates through reforms face a choice between welfare cuts and tax increases - or a combination to secure long run fiscal sustainability. The purpose of this paper is to look into another possible adaptation to the demographic prospects, i.e. full time or more probably part time work after retirement. We focus here on work either beyond the normal retirement age or after entry to an early retirement program. We examine the extent of work among both 60-64-year-olds and individuals above the age of 65, trends in the characteristics of those working after retirement, and gender differences in these respects. More exact knowledge about trends in paid work after retirement - a potential 4th pillar in the overall pension system - is important for policy makers in the area of pension reform.

We use Danish panel data in the analyses in the paper. Denmark provides a useful setting for examining this topic for several reasons. First, by focusing on Denmark, we add to the fairly scarce literature about recent trends in labor force participation among older workers outside the U.S.A. Next, the existence of a multitude of pathways to retirement in Denmark (Larsen \& Pedersen, 2008) combined with several policy changes in recent decades imply that Denmark is particular useful for studying this topic. Further, Denmark is particular suitable for the study of gender differences in work behavior at older ages because of a high labor force participation rate of women in their late fifties compared to most other OECD countries. In 2010, 77.9 percent of Danish women aged 55 to 59 years participated in the labor force compared to 58.7 percent in the OECD area as a whole (OECD, 2011a). We have access to a large and rich administrative based longitudinal Danish dataset for the period 1980-2009, including annual information on income variables, together with a broad set of demographic and labor market characteristics for the whole Danish population. Finally, 
access to data for the whole population is particularly important in the present context, given the relatively small number of older individuals working at high ages, in particular among women.

In the next section, we present a brief survey of recent literature both in the more broad area of labor force participation among older people and in the more specific area of labor market activity after retirement. In section 3, we briefly summarize international trends in the effective retirement age and in employment rates among the 65-74-year-olds. In section 4, we describe recent Danish changes in policy and regulations in the pension area of relevance for this paper. Further, we show recent trends in Denmark in both the average age for entering a retirement program and the employment rate for older individuals. In section 5, we present the results from a number of regression analyses conducted for men and women separately in which the propensity to have paid work after retirement is related to a number of background factors. Section 6 concludes the paper.

\section{Earlier studies}

One of the dominant results so far in the retirement and pension literature has been the strong incentive impact from rules in social security programs. A high implicit tax on continued work from a specific age has been one of the main explanations for the decline in average retirement ages, see Gruber and Wise (1999). Recently, however, a small empirical literature has treated a change in this pattern in the form of increasing labor force participation rates among people above the main social security retirement age. According to Komp et al. (2010) this represents a gradual shift in focus from studying early retirement to labor force participation in the $60-70$ years old group. Most of the empirical contributions focus on this trend in the U.S. labor market but as shown in Section 3, a trend towards higher labor force participation after the normal retirement age is observed also in a number of other countries.

Munnell and Sass (2008) is a broad analysis of later retirement as an instrument to solve the financial problems for the U.S. social security program. Obviously, later retirement is in general also an option relative to the demographic challenges facing most OECD countries. Munnell and Sass (2008) includes health prospects, supply decisions among older workers, the challenge on the demand side relative to an increasing number of older workers along with a discussion of policy options. Another more general approach in meeting the demographic challenge through working longer is found in Maestas and Zizzimopolous (2010). The starting point in the paper is the 
observed turn around in labor force participation among older workers. Maestas and Zizzimopolous (2010) discuss this in relation to a number of possible explanatory factors: secular changes in the skill composition of the labor force, technological change removing the very physically demanding jobs along with changes in the incentive structure inherent in the social security programs and in employer provided pensions.

Another more general approach is found in Maestas (2010) with focus on so-called "un-retirement" in the U.S. labor market, implying a process of exit from the former job to a period of full retirement followed by a return to the labor force. Maestas (2010) find that men are more likely to un-retire than women and that un-retirement is similar to partial retirement in many respects except from the fact that those un-retiring are more likely to change occupation. Maesta (2010) argues that un-retirement could either reflect unexpected financial or health changes or be the expression of an earlier post-retirement plan.

In Kim and Feldman (2000), the topic is bridge employment, a job between a full-time position and permanent withdrawal from the workforce. Among other things, their results suggest that accepting a bridge employment is positively associated with excellent health, organizational tenure, and having a working spouse and dependent children, while it is negatively related to age and salary.

A number of studies focus on the trend in labor force participation among older people in the U.S. Haider and Loughran (2001) focus on the 15 percent in the 65+ group who are employed. Employment in this group correlates positively with health, education and wealth. They find a tendency in the group to work for low wages relative as well to younger people as to own earlier wages. Consequently, non-pecuniary factors appear to be important for this group.

Williamson and McNamara (2001) analyze the determinants of labor force participation in the U.S. in 1998 based on the Health and Retirement Survey. They relate to gender, age and race on the supply side and point to the need for demand side flexibility regarding part-time work and other flexible routes to retirement. Friedberg (2007) focus on the declining labor force participation rate until the mid-1990s, followed by a leveling off and a trend upwards for older workers in more recent years. Friedberg (2007) points to changes in social security program incentives, in employer provided pensions and in health care as potential explanations of this profile. 
Johnson et al. (2007) analyze expected future demand in the U.S. labor market along with changes in the nature of work. Based on this, their expectations of future employability of older workers are positive. Gendell (2008) and Shattuck (2010) both focus on recent developments in the U.S. labor market with increasing employment of men 65 years and older, with nearly half of them being employed in full time jobs. However, both find stronger increases in relative terms among older women, and for older women with a college education in particular. Finally, Toossi (2009) analyzes the expected growth in the U.S. labor force. In spite of the increased participation in the 65+ group, a decline is expected - not in the labor force - but in the growth rate of the labor force.

Only few empirical studies of recent changes in labor force participation among older individuals focus on labor markets outside the U.S. Klevmarken (2010) is a very comprehensive study of work activity among individuals above the age of 65 in Sweden supplemented with a cross country study based on SHARE data. McNair (2006) is another survey based study focusing on Britain. The findings are among others that the 50+ group in the labor force generally show positive attitudes to work but that a gradual polarization is present in the labor market at an increasing age. Suggested policies to delay retirement include continued training also for older workers and a better understanding of the diversity of older workers.

Komp et al. (2010) is another empirical study using SHARE data to study the propensity for having paid work between ages 60 and 70 in 11 European countries in 2005. This propensity is found to be especially high in Denmark, Sweden and Switzerland and especially low in Belgium and France, reflecting among other things program differences regarding early retirement. Some main results are the finding of occupational prestige - as one factor in socioeconomic status - to have a significant positive impact on the propensity. Interacting occupational prestige with the relative importance of private pensions, Komp et al. (2010) find a negative impact.

Dalen et al. (2010) in a survey based study mainly of Dutch employers shift the focus to the demand side regarding paid work among older workers. Size of the organization is found to be an important variable relative to adapting to an ageing workforce. However, many Dutch firms seems at the time of the survey to have a personnel policy with “opposite” age discrimination, i.e. a policy relative to 
older workers that in economic terms increases their effective wage. Very few firms seem to follow policies designed to make productivity and wages match better over the life cycle of workers.

\section{Recent international trends in labor market activity at older ages}

The demographic challenge is found in most OECD countries in varying degrees. In this section, we look briefly into whether there seems to be any adjustment to this challenge. Hence, we consider whether early retirement is countered or reinforced by labor market activity at older ages. That is, we examine the trends in the average effective age of retirement and employment rates for 65-74year-olds in a number of selected OECD countries for men and women respectively, see Figures 1 and 2.

First, we look at the average effective age at retirement for the period 1970-2009, (OECD (2011b)). The average effective age of retirement is calculated as the average age at exit from the labor force during a 5-year period, see also Figure 1. We divide the presentation - also for clarity - in Figures 1a and 1c including countries with fairly homogenous trends, in particular for men, and Figures $1 \mathrm{~b}$ and $1 \mathrm{~d}$ covering countries with more heterogeneous trends.

In Figure 1a, Sweden and four Anglo-Saxon countries show a profile of declining effective retirement ages for men until the mid-1990's followed by an increase. However, the effective age at retirement in 2009 is lower than in 1970. That is, the effective age at retirement has declined with 2 - 3 years from 1970 to 2009 in these countries. In Figure 1b, France and Switzerland face the steepest decline in the effective age during the four decades, i.e. from 68 to 59 years in France and from 72 to 66 years in Switzerland. Further, during the last decade the effective age in these countries is either fairly constant (France) or quite volatile (Switzerland). The effective age in Finland and Denmark is at about the same level as in France in 1970 (66-68 years), but an increase in these countries during the most recent decade implies a higher level in 2009 compared to France (64 years in Denmark and 62 years in Finland). Germany faces a similar increase. ${ }^{1}$ Overall, after a decline until the mid- or late 1990's the average effective age of retirement has been increasing for men during the most recent decade in most countries.

\footnotetext{
${ }^{1}$ Data for Germany is only available from 1996 and on.
} 
In almost all the countries, the average effective age at retirement is lower for women than for men, see Figures 1c and 1d. The only exceptions are found in the U.S.A., Finland and France where the age for men and women is at the same level. However, the profiles for women are similar to that for men, i.e. women experience a decrease in the effective age followed by an increase in the most recent decade.

Next, we consider employment rates for the age group 65-74 years in the period 1980-2009, see Figure 2. Usually, unemployment benefits are not available after age 65 and therefore, Figure 2 shows employment rates rather than labor force participation rates. Obviously, the graphs should not be read as indicating the shares engaged in full time, whole year, employment. Instead, they show the shares of people aged 65-74 years classified as employed according to labor force surveys. That is, they are either employed for pay for at least one hour, self-employed, assisting spouse, or temporarily out of employment due to e.g. holiday, illness or maternity leave during the reference week. 
Figure 1. Average effective age of retirement for men (a, b) and women (c, d) separately, selected OECD countries, 1970-2009. Source: OECD (2011b).

a)

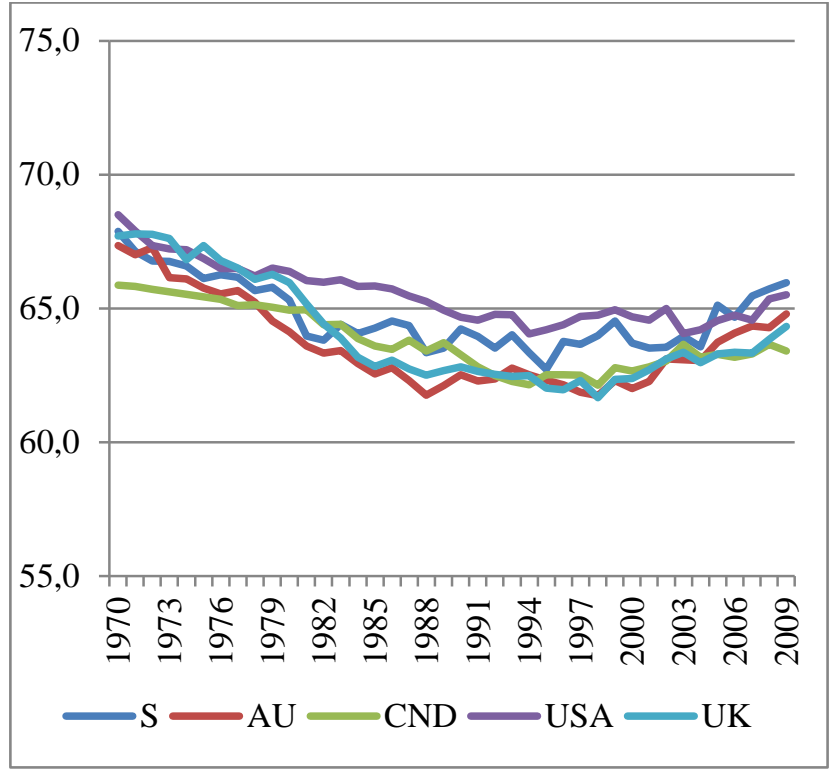

c)

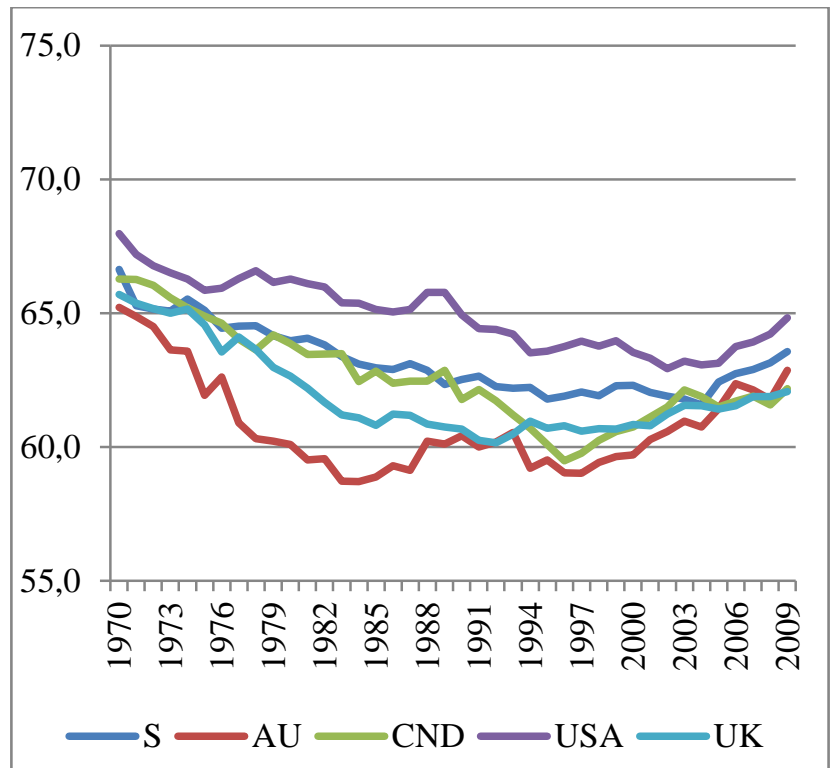

b)

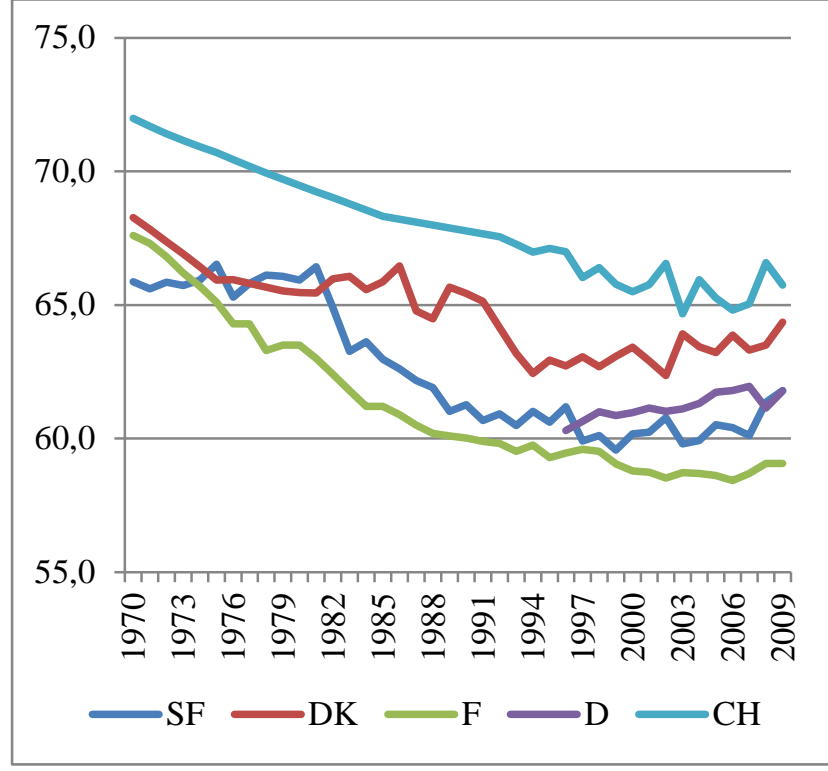

d)

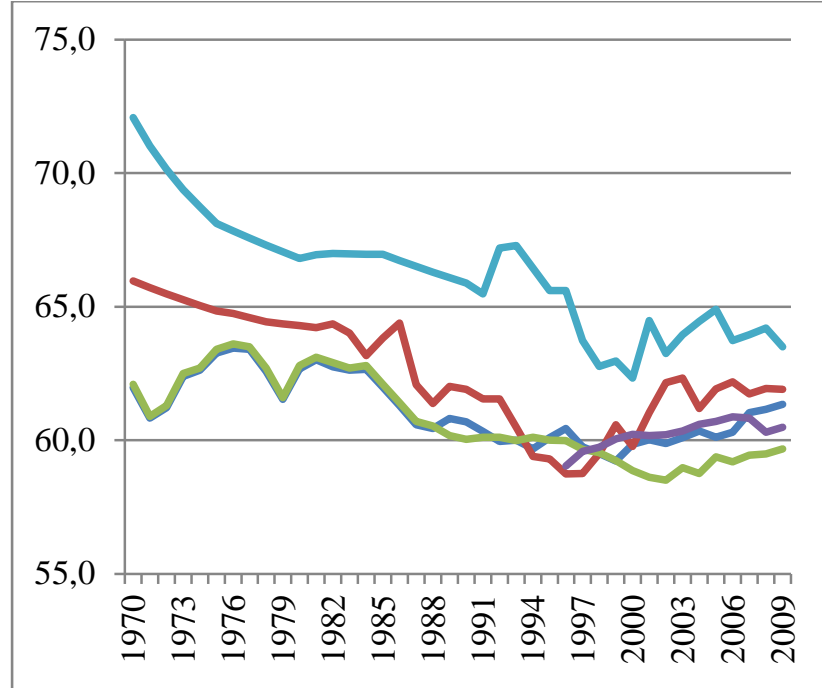

$\longrightarrow \mathrm{SF} \longrightarrow \mathrm{DK} \longrightarrow \mathrm{F} \longrightarrow \mathrm{D} \longrightarrow \mathrm{CH}$

Notes: The average effective age of retirement is calculated as a weighted average of (net) withdrawals from the labour market at different ages over a 5-year period for workers initially aged 40 and over. In order to abstract from compositional effects in the age structure of the population, labor force withdrawals are estimated based on changes in labor force participation rates rather than labor force levels. These changes are calculated for each (synthetic) cohort divided into 5-year age groups. The OECD estimates are based on the results of national labor force surveys, the European Union Labour Force Survey and, for earlier years in some countries, national censuses. 
Figure 2. Employment rates for 65-74-year-olds for men (a, b) and women (c, d) separately, selected OECD countries, 1980-2009. Source: OECD.

a)

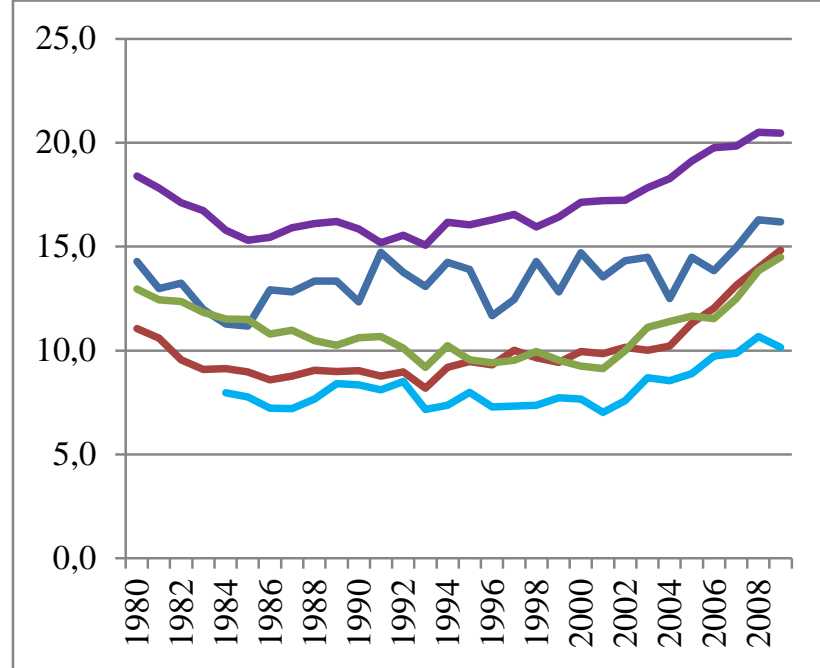

$\longrightarrow \mathrm{S} \longrightarrow \mathrm{AU} \longrightarrow \mathrm{CND} \longrightarrow \mathrm{USA} \longrightarrow \mathrm{UK}$ b)

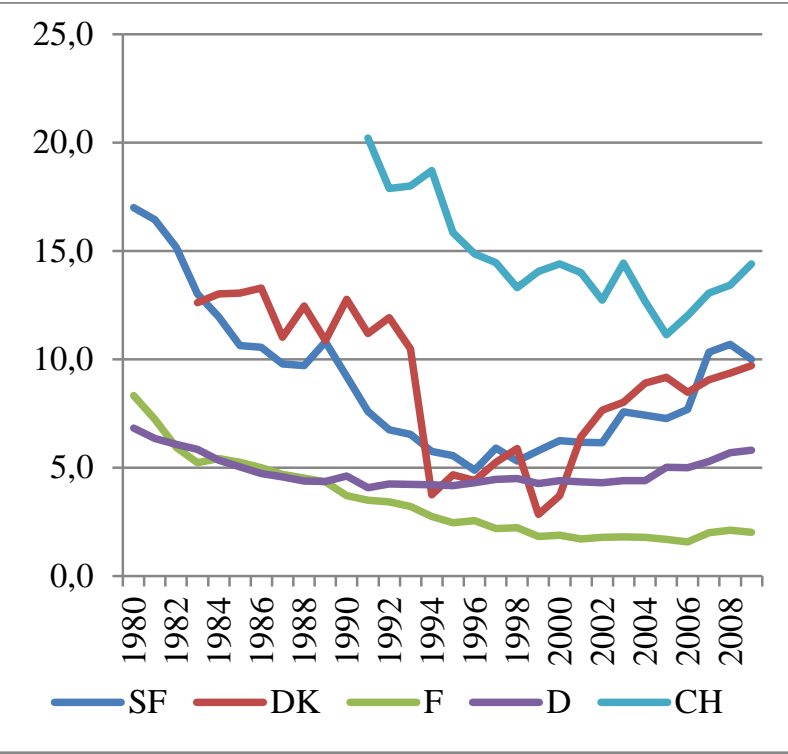

d)

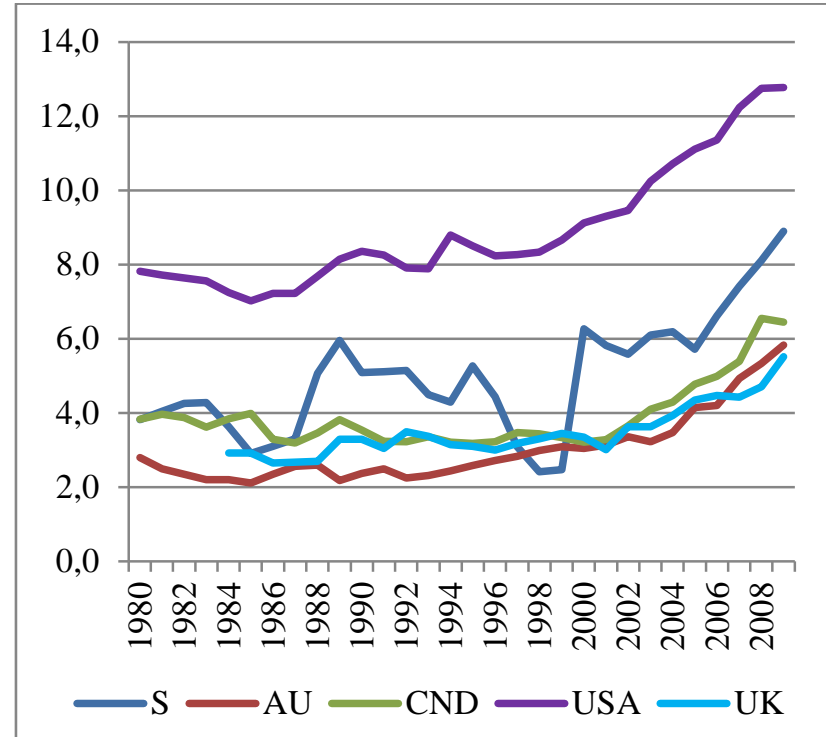

With these reservations in mind, we first show the trends for men in Figures 2a and 2b. We divide the presentation into the same groups of countries as in Figure 1. In this context, the countries in Figure 2a have fairly high employment rates for 65-74-year-old men while the countries in Figure 2b have lower employment rates. 
In Figure 2a, Sweden along with four Anglo-Saxon countries show a profile of declining employment rates until the mid-1990s. In Sweden, employment returns to about the same level in 2009 as back in 1980. In contrast, the four Anglo-Saxon countries show increases up to between 10 per cent in the UK and 20 per cent in the U.S.A. In Figure 2b, five other countries show quite different movements around lower levels. In Denmark and Finland, employment rates have been increasing since the late 1990s to around 10 per cent. In Germany, the employment rate is nearly flat around 5 per cent. In France, we see a strong decline from around 8 to around 2 per cent. Overall, the variation in men's employment rates seems impressive, from 2 percent in France to 20 per cent in the U.S.A. However, the general picture is that the employment rate for 65-74-year-old men has been increasing, in particular in the most recent years.

Figures 2c and 2d show quite different profiles for 65-74-year-old women. For UK, Australia and Canada, employment rates are very similar, i.e. between 2 and 4 per cent until an increase takes place up to a level of 6 per cent in 2009. In Sweden and the U.S.A., a quite strong increase occurs from the mid-1990s, up to 13 per cent for the U.S.A. In Figure 4b, women in France follow the same trend as men, reaching a level below 1 per cent in 2009. The remaining four countries in Figure 2d show somewhat erratic, small increases since the turn of the century. As for men, the gap between top and bottom is impressive for women, i.e. between less than 1 per cent in France and 13 per cent in the U.S. Overall, however, the employment rate has been increasing also for 65-74-yearold women, in particular in the most recent years.

The overall conclusion from these recent international trends seem to be that working more, also for the 65+ group, is a relevant contribution to reduce the pressure from population ageing. Hence, the trend toward early retirement has been countered by increases in both the average effective age of retirement and in labor market activity beyond the mid-60's. In the next section, we proceed to look into the prospects for paid work after retirement in Denmark.

\section{Trends in Denmark in recent decades}

In this section, we first outline the policy setting around retirement and paid work after retirement in Denmark. Next, we present some recent trends in the age of making a transition from the labor force to a formal retirement program. Further, we summarize evidence on labor market activity for 
the 60 - 64 years old - typically eligible for early retirement programs - and for the 65 - 74 years old group.

The main retirement program in Denmark in the area of Social Security is Old Age Pension (OAP) a PAYG program for which everybody are eligible from age $65^{2}$. The other main program is Social Disability Pension (SDP). Depending on visitation on medical and/or social criteria this program is open for everybody 18 - 64 years old. The main program for early retirement is the socalled Post Employment Wage (PEW) which was introduced in 1979. Since then, there has been a number of policy changes tightening access to the program. Conditional on a sufficient long membership in an Unemployment Insurance fund and on being in the labor force at age 59, people are eligible for entry to the program between age 60 and $64^{3}$. Entry can occur at any age from 60 but benefits in the program are higher if entry is postponed to at least age $62^{4}$. Since a reform in 1999 there has been great flexibility regarding rules for working while being in the program, i.e. working for pay in a specific number of hours simply results in a proportional reduction in PEW benefits.

In recent years a number of policy changes have been implemented with the common purposes of increasing incentives to work beyond 65 and to reduce or dismantle barriers for continued work. Work beyond 65 can take many forms, i.e. continue in present job - or another - either full time or part time job, or in a bridge job between former job and full retirement. It has become possible to delay take up of OAP on actuarial conditions until age 75. This option is conditional on having a minimum of 1000 hours of work annually. Further, means testing of supplementary OAP against income from work has been reduced. Take up of labor market and private pensions can - with actuarial adjustment - be delayed until 75 and certain groups of public sector employees have no longer mandatory retirement.

In this section we will look into whether these policy changes along with an eventually underlying trend have had an impact on indicators for labor market activity beyond age 60 in Denmark. We look first into the recent trend in average retirement age and next we illustrate a number of indicators for the extent of $60+$ labor force participation. This is followed by descriptive indicators of the share in the age group with positive earnings from work.

\footnotetext{
${ }^{2}$ For people born before april 1, 1939, the eligible age was 67.

${ }^{3}$ Before the change in the OAP age PEW was open between ages 60 and 66.

${ }^{4}$ Entry before 62 implies means testing of the benefits against other pension programs.
} 


\section{Recent trends in retirement age and older workers' employment}

In this section we relate the policy changes and reforms described above to observed changes in the average age at retirement and in employment rates for individuals 60 - 64 years old and individuals older than the normal retirement age. In Figure 3 we show the average age at retirement from 1980 to 2008, conditional on being in the labor force in the year preceding entry to a retirement program. People entering retirement programs from a state outside the labor force are thus excluded in the calculation behind Figure 3. The consequence of this is the finding of a lower average age compared with more summary calculations where e.g. housewives entering OAP at age 65 contribute to a higher estimate of the age at retirement than the relevant estimate when focus is on the labor market.

The profiles in Figure 3 shown separately for women and men are dominated by program innovations and reforms while the business cycle illustrated in the appendix with the aggregate unemployment rate from 1979 seems to have much less of an impact. The average age at entry to a retirement program from the labor force declined with about a year from the introduction of the PEW program in 1979 until a new stationary level from the mid-1980s. The dramatic temporary decline in the mid-1990's reflects the opening of a specific program, called the Temporary benefit program, TBP. From 1992 to 1994, long term unemployed people aged 55-59 years could leave the labor force through this program. Benefits were 82 percent of maximum unemployment insurance benefits and from age 60 recipients were transferred to PEW. From 1994 to 1996, TBP was open also for long term unemployed aged 50-54 years. In 1996, entry to this program was closed. From 1996 the average age returns to the mid-1980s level followed by an increase of slightly more than a year from the turn of the century. This upward trend may reflect the combined effect of policy changes and an improved cyclical situation. The average age at entry to a retirement program, without conditioning on exit occurring from a state in the labor force, increases also with about one year from 2006 to $2010^{5}$. During the whole period, the trend in the average age is parallel for men and women. In most years, the average age is about one year higher for men than for women except around the dip in the mid-1990s, where the gender difference is about two years reflecting that many more women than men entered the TBP program.

\footnotetext{
${ }^{5}$ Based on data kindly supplied by the National Association of Insurance and Pension Companies.
} 
Figure 3. Average age for entering a retirement program for individuals coming from a position in the labor force, for all, and for men and women separately, Denmark, 1980-2008. Source: Own calculations on administrative data.

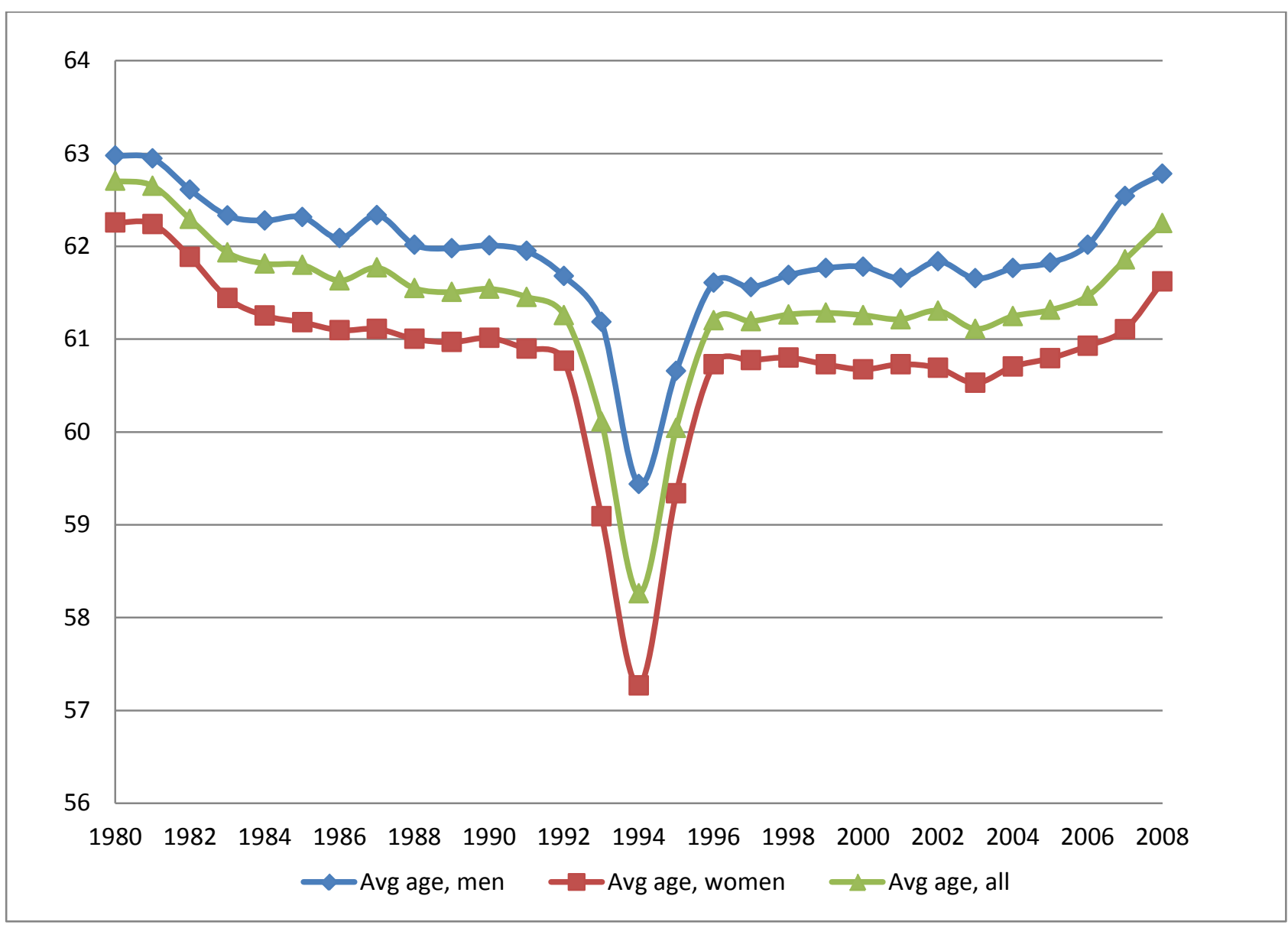

Next, as an example, we look specifically at the trend in the average age at which individuals enter PEW, see Figure 4. The average age is declining until the mid-1980s where all 60 - 66 years old are potentially eligible to the program. From the mid-1980s the average age moves without any reflection of the business cycle but seemingly with some impact from changes in the program where incentives were introduced to make eligible workers delay entry or abstain from entering PEW. From 2004 there is a downward bias in the age as 65-66 years old are no longer eligible for PEW. Again, the profiles for men and women are very similar. The age for entering PEW is about half a year higher for men than for women on average. 
Figure 4. Average age for entering PEW. For all, and for men and women separately, Denmark, 1980-2006. Source: Own calculations on administrative data.

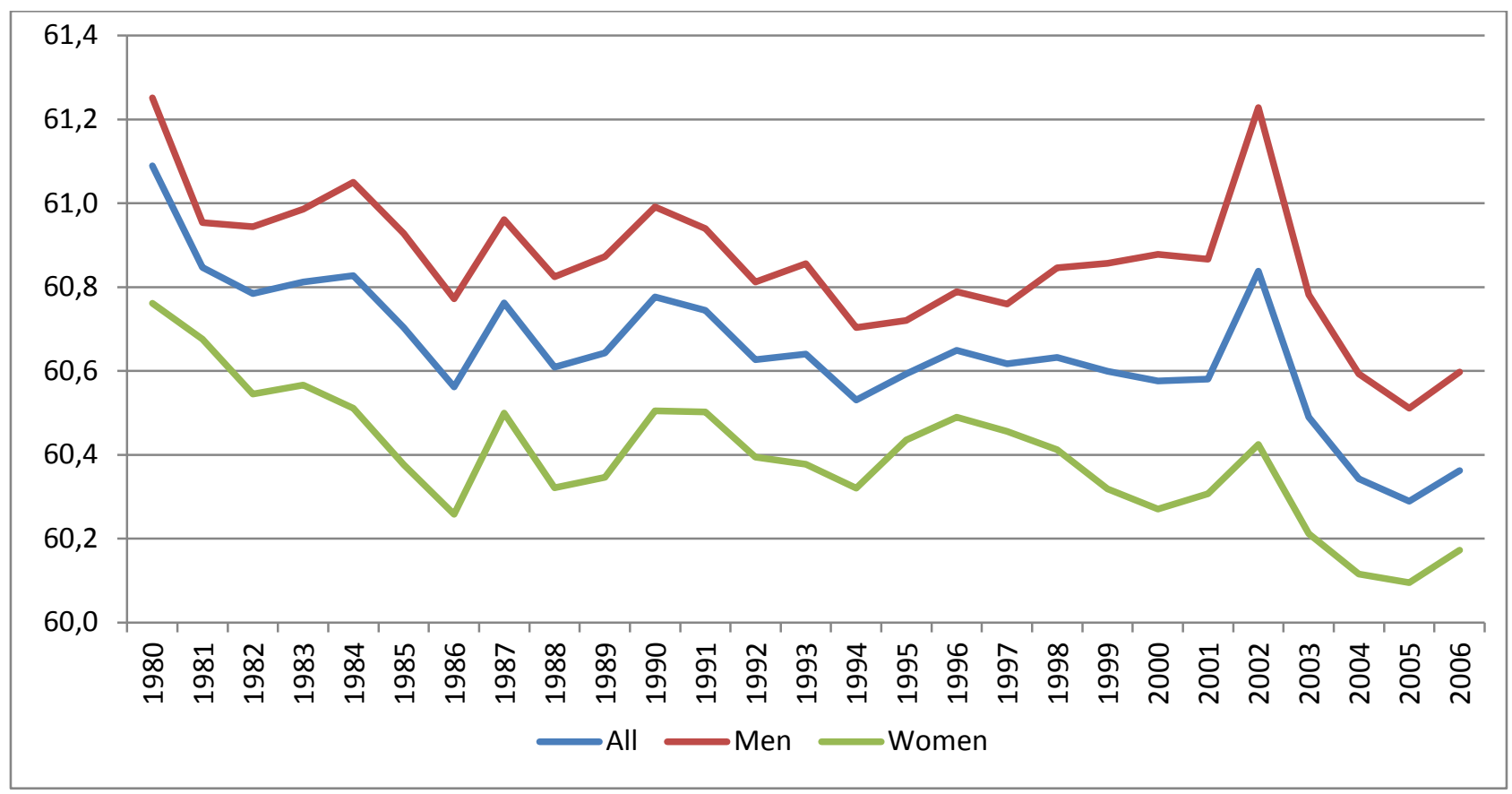

Next, we consider recent trends in employment rates for 60-64-year-olds and for individuals beyond age 65 respectively, see Figures 5a and 5b. Again, we show employment rates rather than labor force participation rates for both age groups. For the 60 - 64 years old employment rates are Ushaped over time. The turning point for both women and men is around the year 2000. For men, the employment rate in 2010 is nearly at the same level as at the time around 1980 when the PEW program was opened. For women, the 2010 level is significantly higher than the initial level, due also to cohort effects over these nearly 30 years. This effect also explains the slightly higher overall employment rate in 2010 in spite of the introduction of the PEW program at the beginning of the period.

For individuals aged 65 years and older, the employment rate is declining until around 2000 followed by a small increase. ${ }^{6}$ For this age group, the employment rate for both men and women is lower today than in the beginning of the 1980s. For men, the employment rate goes from 23 percent in 1980 to 16 in 2010. The corresponding figures for women are 6 and 5 percent respectively.

\footnotetext{
${ }^{6}$ Klevmarken (2010) finds, working with SHARE data, that the labor force participation rate 65+ increases significantly in Switzerland, Denmark and Sweden.
} 
Figure 5. Employment rates for individuals a) aged 60-64 years and b) beyond 65 years, for all and for men and women separately, Denmark, 1981-2010. Source: Statistics Denmark (2011).

a)

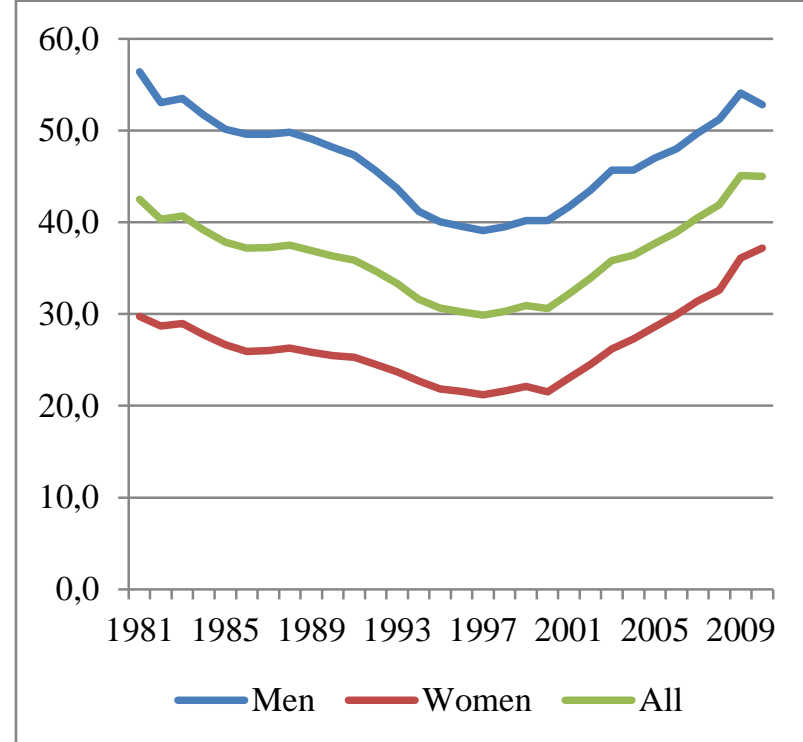

b)

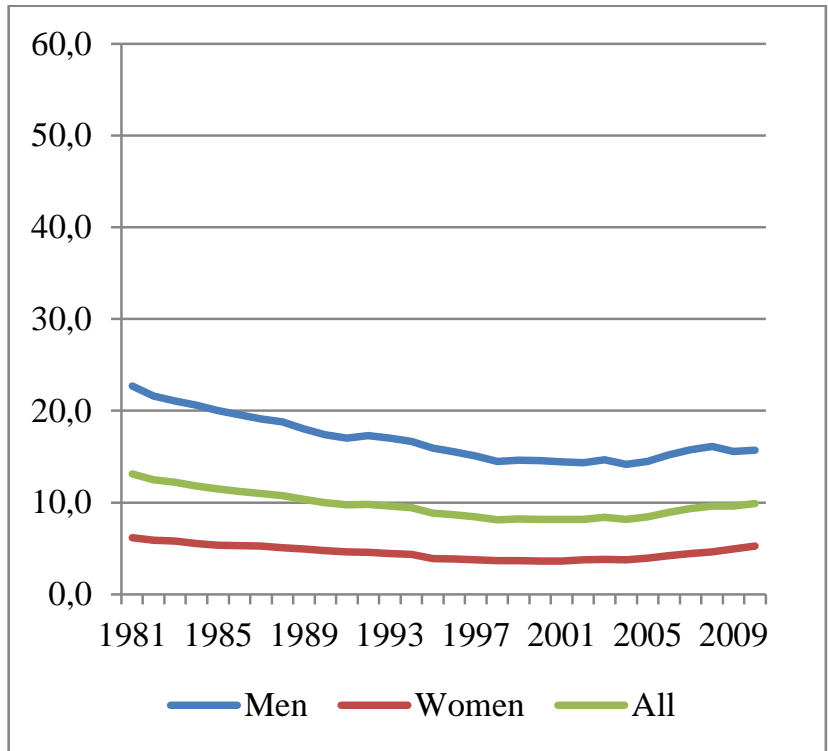

Presumably, both policy changes and the business cycle have contributed to the increasing trend in employment rates since the turn of the millennium for the 60-64-year-olds in particular. This suggests that the policy changes introduced to continue having paid work after entering a retirement program, in particular PEW, have worked as intended. Other policy measures creating incentives to abstain from entering PEW at all have worked in the same direction. Because of the introduction in 1999 of great flexibility in the regulations for having paid work while being on the PEW program, it seems reasonable to believe that the higher employment rate in 2010 compared to the level in the late 1990s represent more 60-64-year-olds working rather than more working hours in this age group.

Another indicator of the extent of labor market participation among the $60-74$ years old is presented in Table 1 showing the share in three age intervals 60 and older with positive earnings, respectively positive income from own business, at five points in time since the late 1980s. Regarding earnings, the biggest change is found for the $60-64$ years old where the share with positive earnings goes up from 33 to 40 percent over the 10 years period 1997 to 2007. In the most recent part of the period, a declining fraction in this age group enter PEW and unemployment was low until well into the years with financial crises. For the two older age groups we find small increases in the shares from the late 1990s. The shares in the three age groups with positive income from own business are falling throughout the period. It is difficult to identify any cyclical variation 
in these numbers. Instead it presumably reflects the long run decreasing share of the labor force with own business.

Table 1.Share with earnings from work and share with positive income from own business by age intervals. Percent.

\begin{tabular}{|l|l|r|r|r|r|r|}
\hline & & 1987 & 1992 & 1997 & 2002 & 2007 \\
\hline \multirow{3}{*}{ Earnings } & Age & & & & & \\
& $60-64$ & 34.1 & 33.2 & 33.1 & 37.4 & 40.3 \\
\cline { 2 - 7 } & $65-69$ & 15.8 & 15.3 & 14.6 & 16.8 & 16.6 \\
\cline { 2 - 7 } & $70-74$ & 6,2 & 7.4 & 5.9 & 6.7 & 8.3 \\
\hline \multirow{5}{*}{ Own business } & $60-64$ & 10.2 & 9.8 & 9.5 & 9.5 & 9.4 \\
\cline { 2 - 7 } & $65-69$ & 8.4 & 7.5 & 7.7 & 6.9 & 6.8 \\
\cline { 2 - 7 } & $70-74$ & 6.4 & 5.8 & 5.9 & 5.4 & 4.9 \\
\hline
\end{tabular}

A major part of the 60-64 years old participate in the PEW program ${ }^{7}$. Throughout the nearly 30 years since introduction of this program, the average age at entry has been fairly stationary as shown in Figure 4. However, the employment profiles in Figure 5a clearly indicate that take-up of this program has been changing over time. This is illustrated, implicitly, in Figure 6 showing the share of participants in the PEW program with earnings above a non-trivial amount in the years 1981-2009. The cut-off point is set at 25.000 DKK in 2006 and is adjusted by hourly earnings in manufacturing industry throughout the period included in Figure 6. For men, Figure 6 shows a fairly stationary level around 20 per cent for the share with earnings above the cutoff point. For women, the share declines from about 20 to about 15 per cent. This, however, is only relevant for the selected group who enter PEW and it should be compared with the strong increase in employment rates for women shown in Figure 5a.

\footnotetext{
${ }^{7}$ Until 2004 the age group with conditional eligibility for this program was the 60-66 years old.
} 
Figure 6. The share of participants in the PEW program with non-trivial earnings from work, women and men, 1981 - 2009.

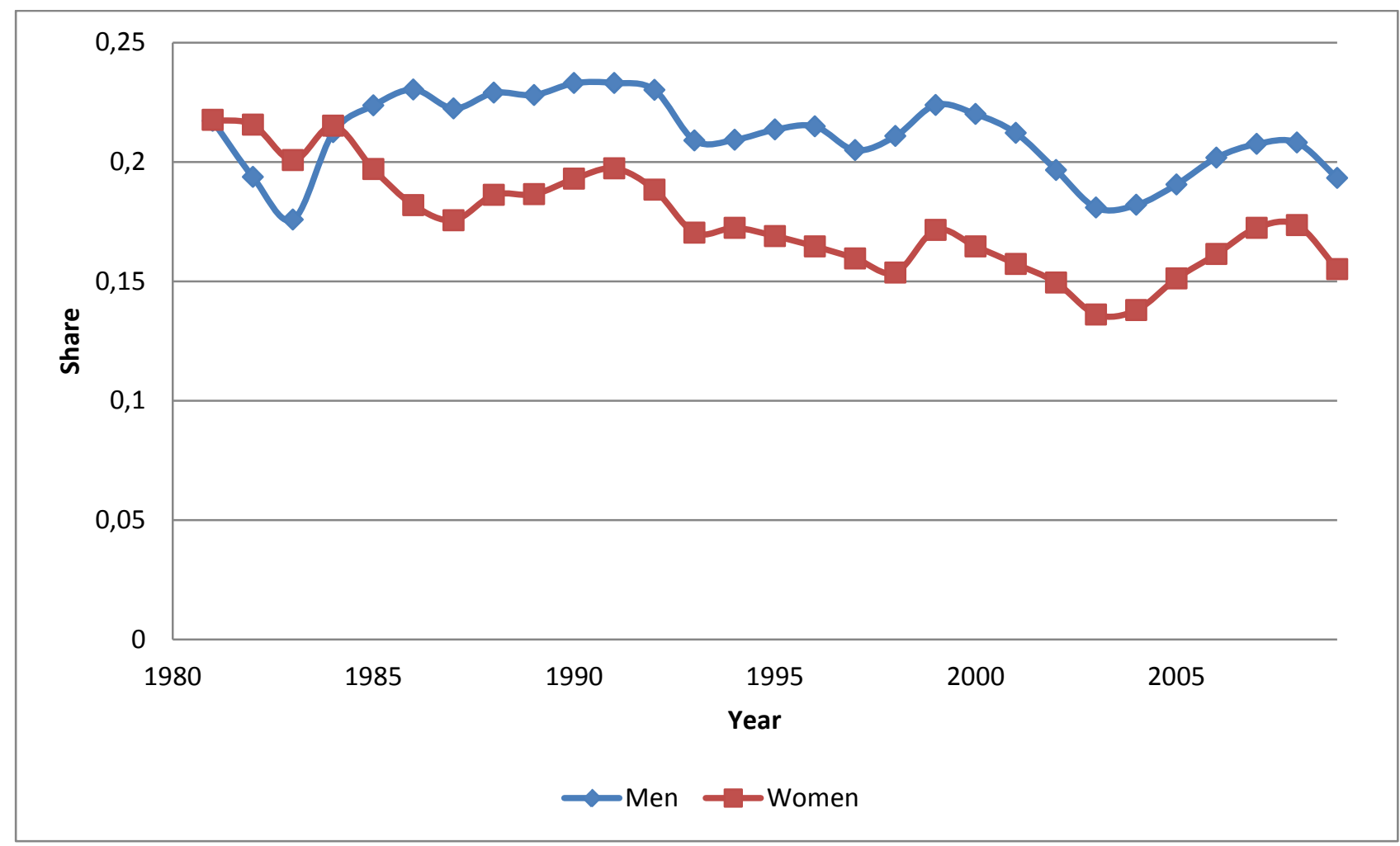

Next, Figure 7 shows the share of women and men 65-74 years old with earnings above the same cutoff point as in Figure 6. The annual data from 1995 supports the evidence in Table 1. They are, however, not directly comparable as Figure 7 conditions on individuals 65-74 years old having been in the labor force at age 59. As our data are available at the individual level only from 1980, Figure 7 has 1995 as the first year of observation. Main results are a strong increase for men and a surprising increase for both women and men in the 2008-2009 years influenced by the financial crisis. 
Figure 7. The share of women and men 65-74 years old with non-trivial earnings from work, 19952009.

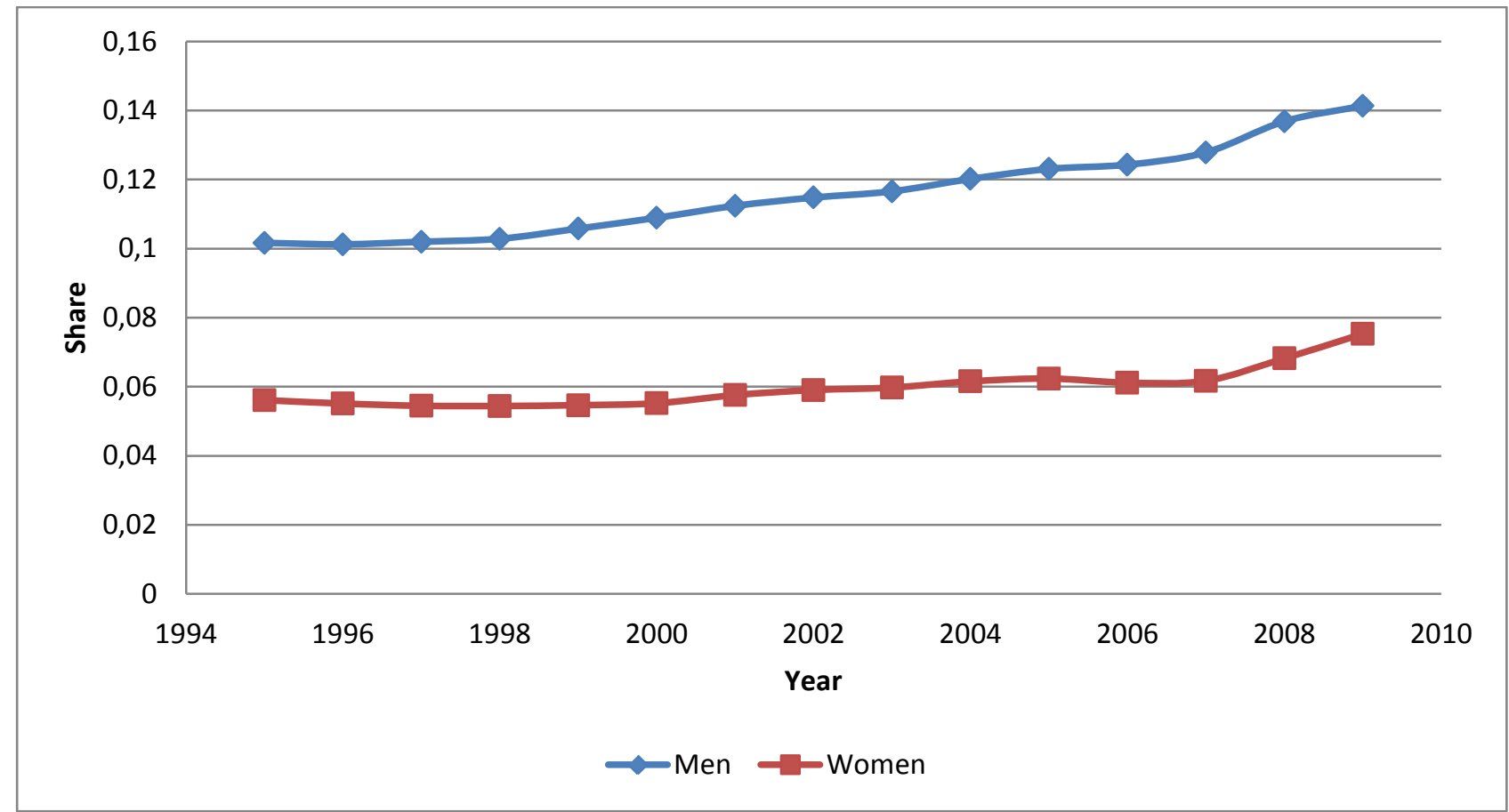

Labor force participation in the 60+ group is strongly dependent on education. This is shown in Figure 8 as an example for 2009 for men aged 60 to 75. The biggest gap is found as expected between individuals with no post-school education and those with a long theoretical education. At the OAP age of 65 about 50 percent of the highly educated are still in the labor force compared with 25 - 30 percent in the other groups. 
Figure 8. Labor force participation rates by education, men, 2009.

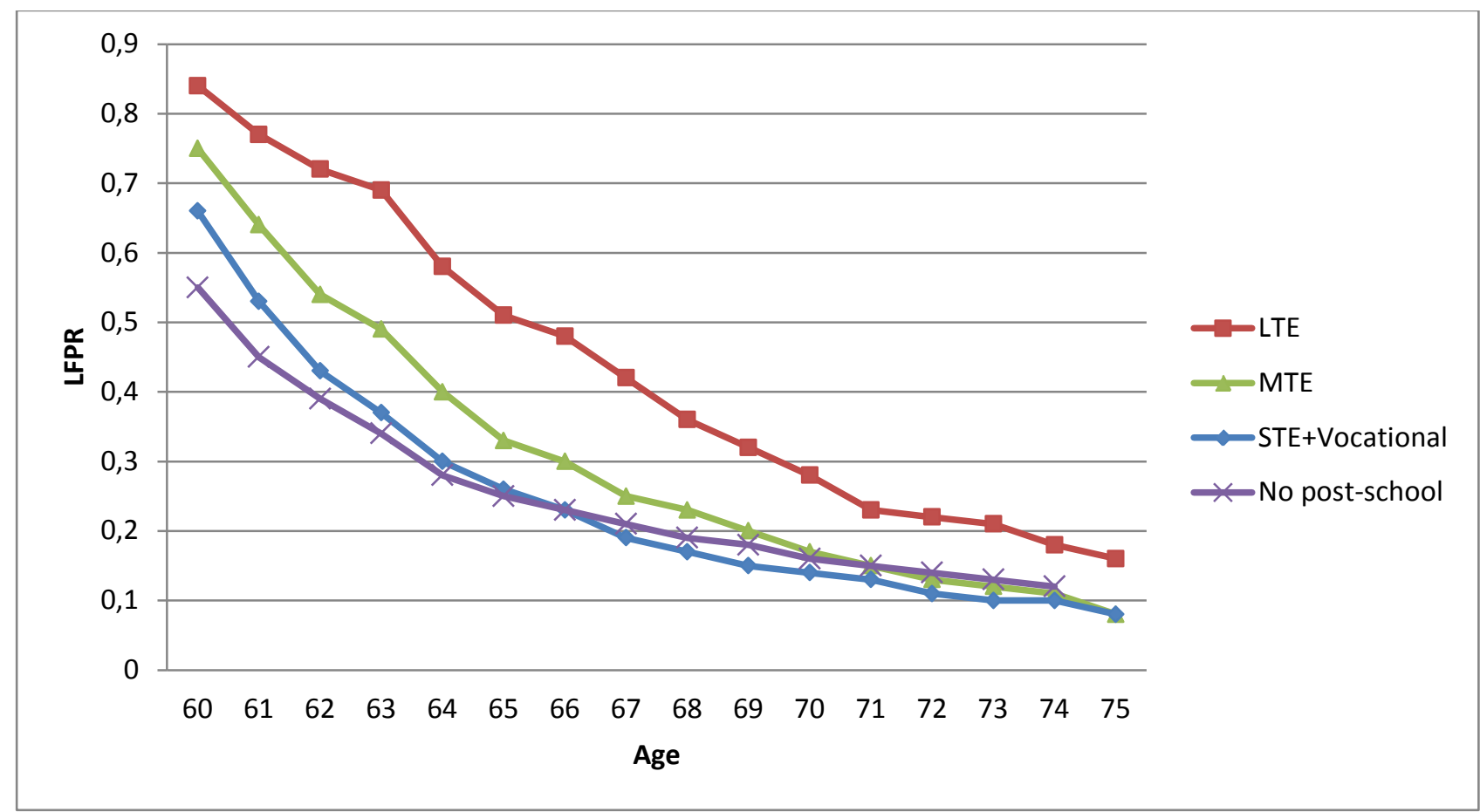

In Figure 9 we illustrate how the share of people with positive earnings change in relation to the number of years since exit from the labor force to PEW, respectively to other forms of pension in 1997. The initial levels differ as expected between 32 percent in the PEW group and 9 percent in the other pension programs group. For both groups the profile is down to around a quarter of the initial level after 11 years. 
Figure 9. Share of entrants to PEW and pension between 1997 and 1998 with positive earnings in subsequent years.

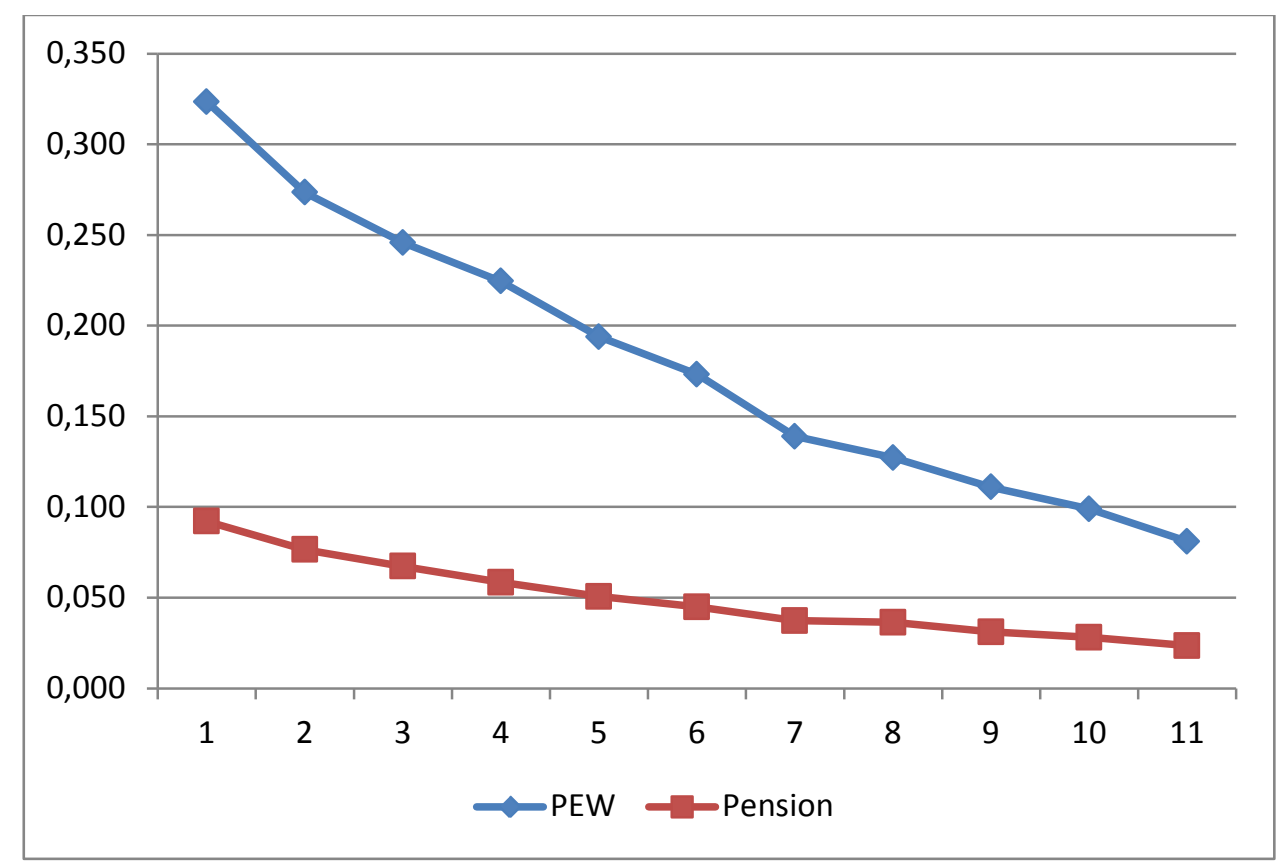

A final aspect is illustrated in Figures 10 and 11, again shown respectively for retirement to PEW and to other pension programs. We have selected the birth cohort 1935 who became eligible for PEW from 1995 and for OAP in 2002. For exit to PEW, it is obvious from Figure 10 that late retirement correlates positively with share having positive earnings. Looking at Figure 11 we find another pattern. Those who retire at the earliest opportunity at age 60 have very little labor market activity after retirement and consequently very little interaction with time after retirement. Those who retire at the OAP age have a steep years after retirement gradient but with an initial level well above those who retired at 60 . About the same gradient is found for the in-between group retiring at age 63 but here at a higher level until the early 70s. 
Figure 10. The share with positive earnings after retirement to PEW by age at retirement and years after retirement. Birth cohort 1935.

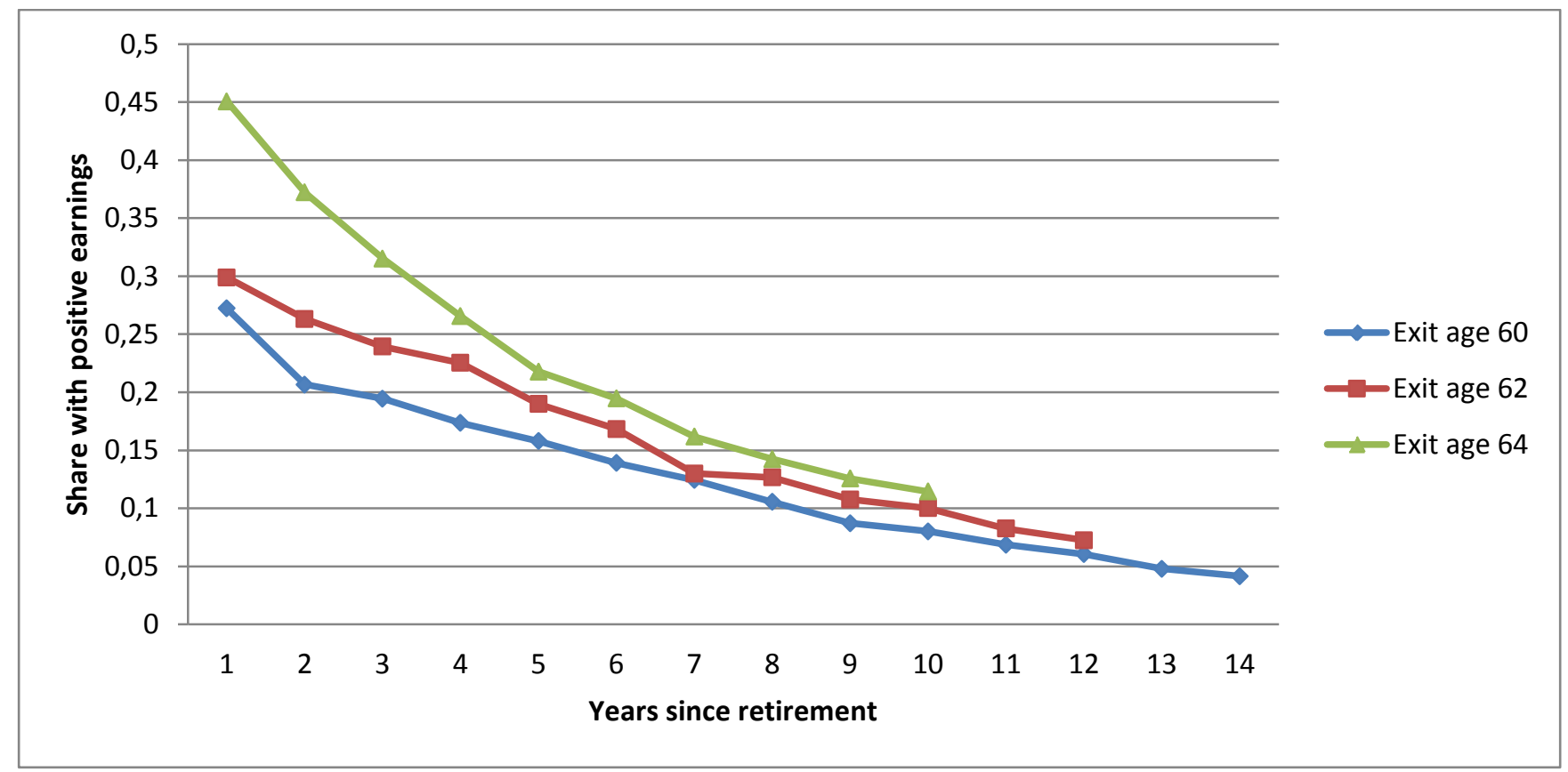

Figure 11 . The share with positive earnings after retirement to other pension programs by age at retirement and years after retirement. Birth cohort 1935

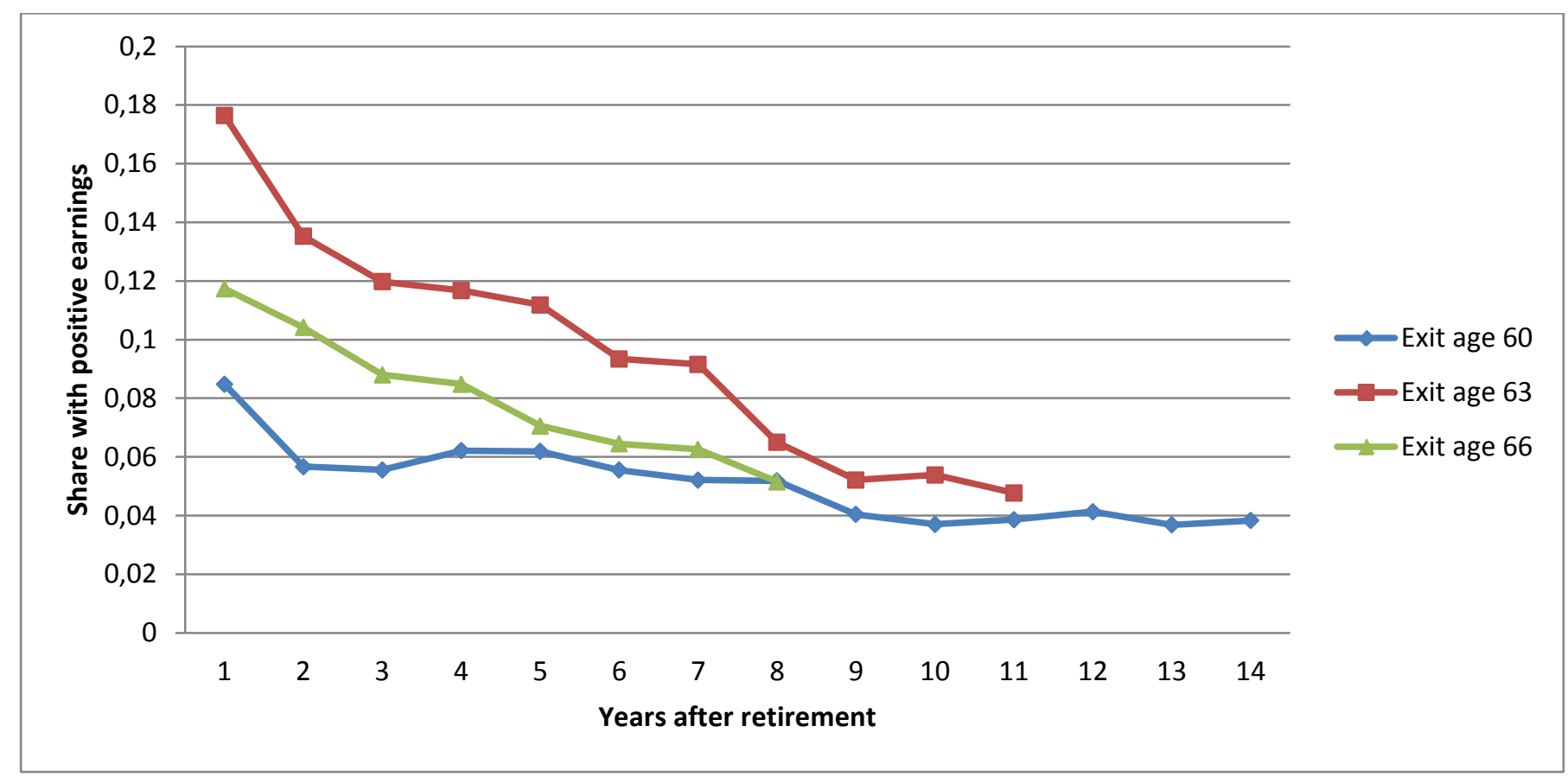




\section{Characteristics of individuals working after retirement}

In this section, we report results from a number of probit regressions of the probability of having a non-trivial labor market activity after retirement. We specify this as having above 25,000 DKK (3400 euro) in earnings from work ${ }^{8}$. In Tables 2 and 3, we show the marginal effects from estimating this probability for the year 2006 separately for people aged 65-74 years, that is individuals who have reached the OAP age, and for people aged 60-64 years who have retired through PEW.

In Table 2, we focus on 65-74-year-old retirees in 2006 who were in the labor force at age 59. For this group, the left hand side variable in Table 2 is set equal to 1 if earnings in 2006 are above 25,000 DKK and 0 otherwise. We include the age of the individual as well as a selection of other explanatory variables and present the results for all and separately for men and women. Looking first at the results jointly for men and women, we find that men have a significantly higher probability of having earnings above 25,000 DKK. In the joint regression, we also find that being married and being owner of your own house or apartment have significant positive coefficients. Further, aggregate unemployment in the year prior to the individual's retirement has a significant negative impact on the probability. The latter result suggests that the labor market situation at retirement has an impact on for instance the demand for "bridge jobs" or other forms of partial retirement. Having paid contributions to labor market pension funds or private pension savings accounts has a positive impact. This finding might be related to the finding of significant and positive coefficients to education with no post-school education as the reference group. Individuals having their own business may at the same time have an income from earnings. We have included a dummy variable for this group but find a significant negative impact on the probability of having earnings above 25.000 DKK. The variable "other income" is the individual income net of earnings from work found to have a negative but very small impact. Finally, the age coefficients have the expected decreasing profile with age 74 being the reference age.

Looking at the separate regressions for men and women, we find that marital status has opposite effects. While men's probability of having earnings above 25,000 DKK is higher if they are married, the reverse is found for women. Overall, the level for the age coefficients is lower for

\footnotetext{
${ }^{8}$ The cut off at 25.000 DKK is somewhat arbitrary. The purpose is to include only non-trivial labor force participation in the estimations.
} 
women than for men and the probability is declining faster for women at increasing age. Further, the gradient in education is steeper for women than for men, and for men only a long education is significant relative to having no post-school education.

Table 2. Marginal effects in probit estimations for having earnings>25.000 DKK (3400 euro), 2006, 65-74 years old.

\begin{tabular}{|c|c|c|c|c|c|c|}
\hline & \multicolumn{2}{|c|}{ All } & \multicolumn{2}{|c|}{ Men } & \multicolumn{2}{|c|}{ Women } \\
\hline & Marg. effect & SE & Marg. effect & SE & Marg. effect & SE \\
\hline Gender & $0.034 * * *$ & 0.001 & - & - & - & - \\
\hline Married & $0.006 * * *$ & 0.001 & $0.017 * * *$ & 0.002 & $-0.003 * *$ & 0.001 \\
\hline Owner & $0.013 * * *$ & 0.001 & $0.011^{* * *}$ & 0.001 & $0.013 * * *$ & 0.001 \\
\hline Other income & $-0.000 * * *$ & & $-0.000 * * *$ & & $-0.000 * * *$ & \\
\hline Pens_contr. & $0.008 * * *$ & 0.001 & $0.011^{* * *}$ & 0.001 & $0.006^{* * *}$ & 0.001 \\
\hline Own bus. & $-0.017 * * *$ & 0.001 & $-0.020 * * *$ & 0.002 & $-0.016 * * *$ & 0.001 \\
\hline U_year_before & $-0.011 * * *$ & 0.000 & $-0.013 * * *$ & 0.000 & $-0.009 * * *$ & 0.000 \\
\hline Short educ & $0.005 * * *$ & 0.001 & 0.000 & 0.001 & $0.010 * * *$ & 0.001 \\
\hline Medium educ. & $0.004 * *$ & 0.001 & 0.004 & 0.002 & $0.007 * * *$ & 0.002 \\
\hline Long educ. & $0.034 * * *$ & 0.003 & $0.033 * * *$ & 0.004 & $0.052 * * *$ & 0.006 \\
\hline 65 years & $0.087 * * *$ & 0.004 & $0.120 * * *$ & 0.007 & $0.049 * * *$ & 0.005 \\
\hline 66 years & $0.076 * * *$ & 0.004 & $0.102 * * *$ & 0.006 & $0.046^{* * *}$ & 0.005 \\
\hline 67 years & $0.065 * * *$ & 0.004 & $0.091 * * *$ & 0.006 & $0.037 * * *$ & 0.005 \\
\hline 68 years & $0.055^{* * *}$ & 0.004 & $0.076 * * *$ & 0.006 & $0.032 * * *$ & 0.004 \\
\hline 69 years & $0.041 * * *$ & 0.003 & $0.059 * * *$ & 0.005 & $0.023 * * *$ & 0.004 \\
\hline 70 years & $0.033 * * *$ & 0.003 & $0.050 * * *$ & 0.005 & $0.015 * * *$ & 0.004 \\
\hline 71 years & $0.028 * * *$ & 0.003 & $0.043 * * *$ & 0.005 & $0.011^{* *}$ & 0.004 \\
\hline 72 years & $0.019 * * *$ & 0.003 & $0.029 * * *$ & 0.005 & $0.010 * *$ & 0.004 \\
\hline 73 years & $0.010 * *$ & 0.003 & $0.013^{* *}$ & 0.005 & 0.006 & 0.004 \\
\hline No. of obs. & & 302159 & & 163699 & & 138460 \\
\hline
\end{tabular}

We have run the regressions in Table 2 also for the years 1995 and 1999. Results are available on request. The main difference comparing the 1995 results to those in Table 2 for 2006 is that age dummies are only significant for the 65 to 68 years old in 1995 and that unemployment in the year 
before retirement has a positive impact on the probability. In the 1999 estimations the impact from unemployment is negative as found for 2006.

In Table 3, we show the same battery of marginal effects from probit regressions for the PEW group. In the joint regression, we find again a significant positive coefficient for men. Further, we find the same differences between men and women with respect to being married and to education as found for the pension group in Table 2. The age coefficients indicate that 64 years old in the PEW program have the highest probability of working, presumably reflecting differences in the entry age to PEW. Regarding aggregate unemployment in the year prior to retirement we find a positive impact, i.e. the opposite of the finding for the 65 and older group

Table 3. Marginal effects in probit estimations for having earnings $>25.000$ DKK (3400 euro), 2006, 60-64 years old, in retirement program.

\begin{tabular}{|l|l|l|l|l|l|l|}
\hline & \multicolumn{2}{|c|}{ All } & \multicolumn{2}{c}{ Men } & \multicolumn{2}{c|}{ Women } \\
\hline & Marg. effect & SE & Marg. effect & SE & Marg. effect & SE \\
\hline Gender & $0.054^{* * *}$ & 0.002 & - & - & - & - \\
\hline Married & $-0.008^{* * *}$ & 0.002 & $0.022^{* * *}$ & 0.003 & $-0.037^{* * *}$ & 0.002 \\
\hline Owner & $0.022^{* * *}$ & 0.002 & $0.012^{* * *}$ & 0.003 & $0.025^{* * *}$ & 0.002 \\
\hline Other income & $-0.000^{* * *}$ & 0.000 & $-0.000^{* * *}$ & 0.000 & $-0.001^{* * *}$ & 0.000 \\
\hline Pens_contr. & $0.020^{* * *}$ & 0.002 & $0.026^{* * *}$ & 0.003 & $0.016^{* * *}$ & 0.002 \\
\hline Own bus. & $-0.048^{* * *}$ & 0.002 & $-0.061^{* * *}$ & 0,003 & $-0.039^{* * *}$ & 0.002 \\
\hline U_year_before & $0.028^{* * *}$ & 0.001 & $0.030^{* * *}$ & 0.001 & $0.022^{* * *}$ & 0.001 \\
\hline Short educ & $0.017^{* * *}$ & 0.002 & $0.006^{*}$ & 0.003 & $0.027^{* * *}$ & 0.002 \\
\hline Medium educ. & $0.056^{* * *}$ & 0.003 & $0.059^{* * *}$ & 0.005 & $0.071^{* * *}$ & 0.004 \\
\hline Long educ. & $0.159^{* * *}$ & 0.008 & $0.138^{* * *}$ & 0.010 & $0.228^{* * *}$ & 0.015 \\
\hline 60 years & $-0.057^{* * *}$ & 0.002 & $-0.081^{* * *}$ & 0.003 & $-0.028^{* * *}$ & 0.002 \\
\hline 61 years & $-0.045^{* * *}$ & 0.002 & $-0.059^{* * *}$ & 0.003 & $-0.022^{* * *}$ & 0.002 \\
\hline 62 years & $-0.041^{* * *}$ & 0.002 & $-0.057^{* * *}$ & 0.003 & $-0.018^{* * *}$ & 0.002 \\
\hline 63 years & $-0.044^{* * *}$ & 0.002 & $-0.054^{* * *}$ & 0.003 & $-0.027^{* * *}$ & 0.002 \\
\hline No. of obs. & & 151517 & & 72399 & & 79118 \\
\hline
\end{tabular}


For the 60-64-year-olds, we have run the same regressions as in Table 3 for the years 1995 and 1999 ${ }^{9}$. The age dummies are insignificant for men in both 1995 and 1999. The impact from aggregate unemployment in the year prior to retirement is found to have the same positive impact in 1995 as in 2006 while the impact is found to be negative in 1999 as found for the 65-74 years old. The difference between the results for 2006, 1995 and 1999 may reflect several changes in the policy area and in the general cyclical situation. As found in Bingley et al. (2012, forthcoming) take-up of PEW goes down quite strongly from the turn of the century. This may reflect the combined impact from the PEW reform in 1999 and the cyclical improvement occurring until the financial crisis begins in 2008. These factors could obviously influence the propensity to take up PEW among eligible individuals relative to stay on in the labor force.

\section{Concluding remarks}

In the last 10-15 years labor force participation has increased in many countries for people aged 60 and older. In most OECD countries, this is a reversal of a long run trend towards lower average retirement ages. Focus in the present paper is on the experience in Denmark in the last quarter of a century regarding labor force participation in the typical age interval 60-64 years of relevance for early retirement and in the 65-74-year-old group of people above the normal retirement age in the main social security program. In an international comparison, Denmark seems to follow the general trend since the mid-1990s of increasing labor force participation in the 60+ group. So far, this trend has been most pronounced among the 60-64-year-olds and among women.

We find for Denmark that the upward trend in labor force participation since 2000 is attributable more to higher employment rates rather than higher average ages for entering a retirement program. This suggests that the amount of work after retirement has increased in Denmark in this period, in particular among PEW recipients. Presumably, both the business cycle and the policy effort directed toward increasing work among PEW recipients implemented in 1999 has contributed to this increase.

A number of policy changes have been enacted recently with the common purpose of creating incentives to delay retirement among the 65-74 year-olds. Based on register data, we find a fairly

\footnotetext{
${ }^{9}$ The results are available on request.
} 
stable employment rate for men in this age group after a decline until around 2000, but an increasing rate for women.

Regressions on the probability of having earnings above 25,000 DKK after retirement point to a number of significant background factors:

- Positive significance relative to being a man, being married, being owner of your own home, having paid contributions to a pension fund, education

- Age profile: coefficients are decreasing from 65 to 73 years, no clear profile is found for the 60-64 years old

- In separate regressions by gender, we find being married has positive significance for men but negative for women, and a steeper gradient in the impact from education for women

- The aggregate unemployment prior to retirement has no consistent impact over time on the probability of having paid work after retirement. 


\section{Appendix}

Figure A.1. The aggregate unemployment rate in Denmark, 1979-2010, Source: Statistics Denmark.

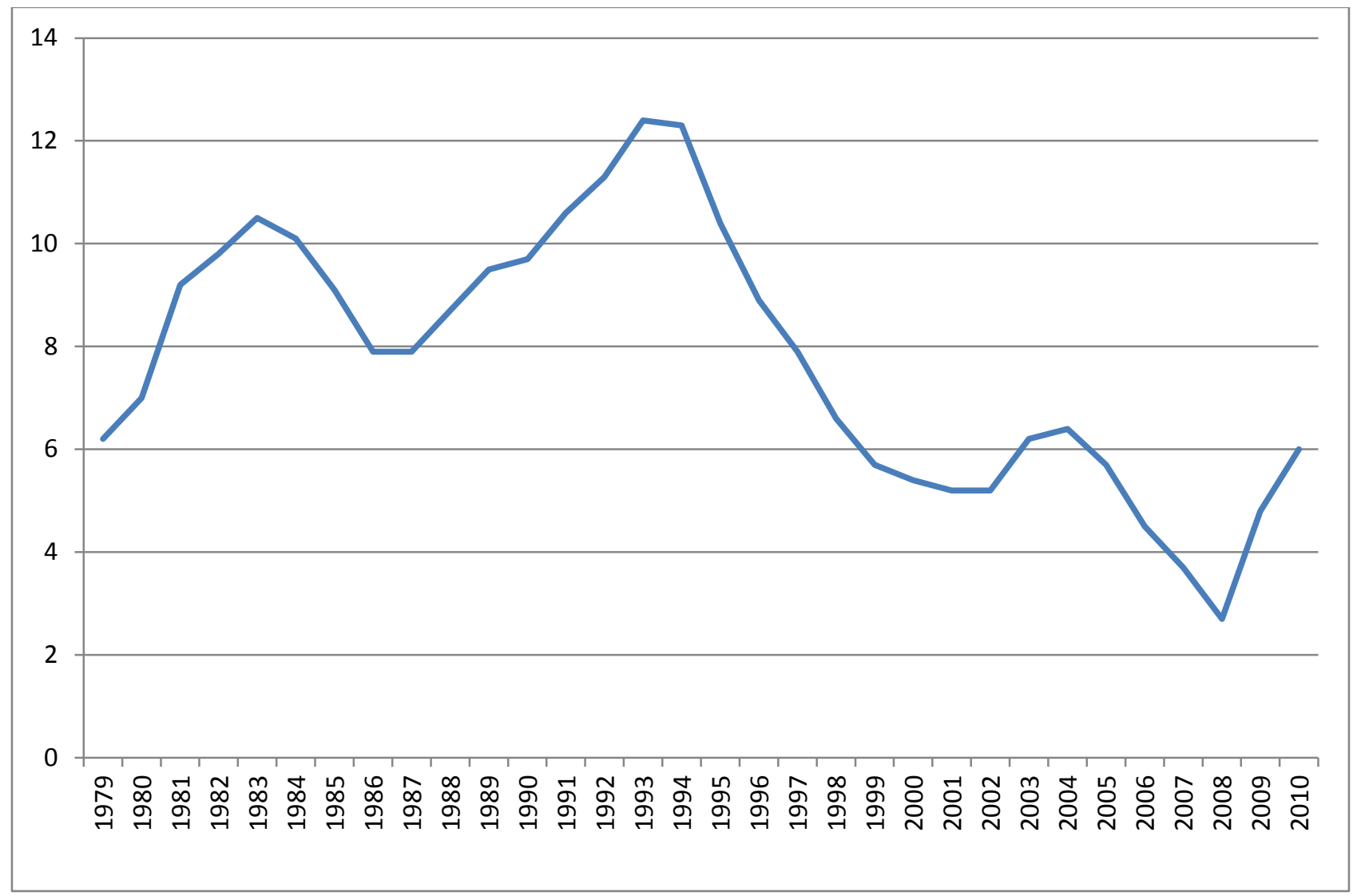




\section{Literature}

Dalen, H.P. van, K. Henkens and J. Schippers. 2010. How do employers cope with an ageing workforce? Views from employers and employees. Demographic Research, Vol. 22, article 32.

Bingley, P., N.D. Gupta and P.J. Pedersen. 2012. Disability Programs, Health and Retirement in Denmark since 1960. Forthcoming in D. Wise (ed.) Social Security Programs and Retirement Around the World. Health and Disability Insurance. NBER. Chicago University Press.

Friedberg, L. 2007. The recent trend towards later retirement. An issue in brief. Center for Retirement Research at Boston College.

Gendell, M. 2008. Older workers: increasing their labor force participation and hours of work. Monthly Labor Review, January: 41-54.

Gruber, J. and D. Wise. 1999. Social Security and Retirement around the World. NBER. University of Chicago Press.

Haider, S. and D. Loughran. 2001. Elderly Labor Supply: Work or Play? Center for Retirement Research at Boston College. WP 2001-04.

Johnson, R.W., G.B.T. Mermin and M. Resseger. 2007. Employment at Older Ages and the Changing Nature of Work. The Urban Institute. 2007-20.

Kim, S. and D.C. Feldman. 2000. Working in Retirement: The antecedents of bridge employment and its consequences for quality of life in retirement. Academy of Management Journal, vol. 43,6: 1195-1210.

Klevmarken, A. and B. Lindgren (eds.). 2008. Simulating an Ageing Population. A microsimulation approach applied to Sweden. Contributions to Economic Analysis no. 285. Emerald Group Publishing, Bingley. UK.

Klevmarken, A. 2010. Vem arbetar efter 65 års ålder? En statistisk analys. (Who works after 65? A statistical analysis). Statens Offentliga Utredningar. SOU 2010:85. Stockholm.

Komp, K., T. van Tilburg and M.B van Groenou. 2010. Paid work between age 60 and 70 years in Europe: a matter of socio-economic status? International Journal of Ageing and Later Life, 5(1): 45-75.

Larsen, M. and P.J. Pedersen. 2008. Pathways to early retirement in Denmark, 1984-2000. The International Journal of Manpower, Vol. 29, 5: 384-409.

Maestas, N. 2010. Back to Work. Expectations and Realizations of Work after Retirement. Journal of Human Resources, 45, 3: $718-748$.

Maestas, N. and J. Zissimopoulos. 2010. How Longer Work Lives Ease the Crunch of Population Aging. Journal of Economic Perspectives, 24, 1: 139 - 160.

McNair, S. 2006. How Different is the Older Labour Market? Attitudes to Work and Retirement among Older People in Britain. Social Policy and Society, 5, 4: 485-494.

Munnell, A.H. and S.A. Sass. 2008. Working Longer. The Solution to the Retirement Income Challenge. Brookings Institution Press. Washington, D.C.

OECD (2011a). OECD.StatExtracts. http://stats.oecd.org (09.11.2011) 
OECD (2011b). Ageing and Employment Policies - Statistics on average effective age of retirement http://www.oecd.org/document/47/0,3746,en_2649_33927_39371887_1_1_1_1,00.html (15.11.2011).

Shattuck, A. 2010. Older Americans Working More, Retiring less. Carsey Institute. Issue Brief.

Statistics Denmark (2011): StatBank Denmark. http://statistikbanken.dk (16.11.2011)

Toossi, M. 2009. Labor force projections to 2018: older workers staying active. Monthly Labor Review, November 2009: 30-51.

Williamson, J.B. and T.K. McNamara. 2001. Why some workers remain in the labor force beyond the typical age of retirement. Center for Retirement Research at Boston College. WP 2001-09. 